\title{
Use of Masonry Construction \& Demolition Waste in Concrete
}

\author{
Tahir Kibriya ${ }^{1}$, Leena Tahir ${ }^{2}$ \\ Black \& Veatch, Toronto, Canada) \\ ${ }^{2} \mathrm{MSc}$ Structural Engineering, City University, London, UK \\ Email: t_kibriya@yahoo.com
}

${ }^{1}$ Ex Faculty/Head of Civil Engineering Department, NUST, Risalpur, Pakistan (Presently Senior Consulting Engineer,

How to cite this paper: Kibriya, T. and Tahir, L. (2017) Use of Masonry Construction \& Demolition Waste in Concrete. World Journal of Engineering and Technology, 5, 216-231.

https://doi.org/10.4236/wjet.2017.52017

Received: March 2, 2017

Accepted: May 7, 2017

Published: May 10, 2017

Copyright $\odot 2017$ by authors and Scientific Research Publishing Inc. This work is licensed under the Creative Commons Attribution International License (CC BY 4.0).

http://creativecommons.org/licenses/by/4.0/

\begin{abstract}
Massive amounts of brick waste are obtained from demolition of old buildings and structures around the world. With the increased stress on sustainable construction, and environmentally friendly materials and greener concreting practices, a large proportion of such waste bricks are crushed and mixed with normal aggregates for use in concrete. The performance of concrete containing waste brick aggregates partially replacing normal aggregates have not been investigated for their performance. This paper covers investigations carried out on concrete with such aggregates obtained from demolition waste and mixed with varying proportions of normal aggregates to produce concrete. Two types of crushed brick aggregates were mixed with gravel in the ratios of 30:70 and 40:60 by weight and specimen were cast for investigations. Two w/c ratios were investigated. Various tests were carried out to assess the compressive strength of cubes and cylinders of mixed aggregates concrete along with flexural strength, stress/strain behavior, moduli of elasticity, ultrasonic pulse velocity determination, densities, surface absorption, shrinkage and frost resistance. The values obtained from these tests were compared with the values of concrete with normal aggregates (gravel) with similar w/c ratios. While the strength tests and durability tests more or less gave satisfactory results however the larger moisture absorption by the waste brick aggregates reduces the frost resistance capacity somewhat thereby care needs to be exercised in using these mixes in regions/areas susceptible to frost.
\end{abstract}

\section{Keywords}

Demolition Waste, Construction Waste, Recycled Aggregates, Recycled Aggregates Concrete, Sustainable Construction, Environmental Friendly Waste, Green Concrete 


\section{Introduction}

Huge amounts of demolition waste were generated in the world wars. After the Second World War, Germans were the first ones to initiate research on use of waste materials in construction. Massive efforts have gone in research on disposal/ recycling of waste products being generated through various processes. Explorations of possible usage of such wastes in various industries have been carried out extensively. Shortage of development budgets in developing/ under developed countries forces them to make efforts to find cheaper substitutes that are locally available. Furthermore, most of the masonry construction which was built years ago has already outlived their lives and are being demolished thereby creating large quantities of waste brick. Crushed brick aggregates from bricks obtained from demolition/construction waste are usually added to normal aggregates and used for concreting in many countries however, there has been no information nor research on the performance of such concrete in which normal aggregates have been partly replaced with crushed waste brick aggregates exists in literature neither any information on acceptable percentages of such waste aggregates to be used in various concrete mixes are evaluated, to keep the resulting concrete properties acceptable, though concrete with $100 \%$ crushed brick aggregates have been investigated [1]-[8].

\section{Research Significance}

The significance of this research is to investigate the properties of concrete made from partial replacement of natural aggregates in various proportions with abundantly available masonry construction waste from demolition of masonry construction and its use in quality concrete along with requisite care to be practiced in use of such concretes.

\section{Concrete Mixes Used for Experimental Testing}

To investigate the performance of concrete with normal aggregates replaced with a percentage of crushed waste brick aggregates, two sets of specimen were prepared for experimental investigation by replacing $30 \%$ and $40 \%$ by weight of gravel aggregate with crushed waste brick coarse aggregates. The w/c ratios of two characteristic strengths of 35 and $50 \mathrm{~N} / \mathrm{mm}^{2}$ of concrete with gravel were investigated for concrete with mixed gravel and crushed waste brick aggregates. The concrete specimens used as standard to carry out comparative study were prepared by using Thames Valley gravel as coarse aggregates. Water/cement ratio, quality of water, curing conditions and test methods were kept constant for all specimen. Table 1 gives the quantities per cubic meter of concrete. Table 2 and Table 3 give the properties of concrete with mixed aggregates.

\section{Experimental Testing Regime}

Testing regime followed is given below. Four sets of specimen from four different batches were used in all tests:- 
Compressive strength/density

Flexural strength/Shrinkage

Stress/strain behavior

Static modulus of elasticity

Dynamic modulus of elasticity

Ultrasonic pulse velocity
$150 \mathrm{~mm}$ cubes, $150 \mathrm{~mm}$

Diameter, $300 \mathrm{~mm}$ long cylinders.

$150 \times 150 \times 750 \mathrm{~mm}$ beams.

$150 \mathrm{~mm}$ diameter, $300 \mathrm{~mm}$ long cylinders.

$150 \mathrm{~mm}$ diameter, $300 \mathrm{~mm}$ long cylinders.

$150 \times 150 \times 750 \mathrm{~mm}$ beams.

$150 \mathrm{~mm}$ cubes.

Table 1. Quantities per cubic meter of concrete.

\begin{tabular}{|c|c|c|c|c|}
\hline MIX & 11 & 12 & 21 & 22 \\
\hline W/C RATIO & 0.5 & 0.385 & 0.5 & 0.385 \\
\hline Density (average) $\mathrm{kg} / \mathrm{m}^{3}$ & 2330 & 2355 & 2345 & 2360 \\
\hline Cement kg/m & 320 & 415 & 320 & 415 \\
\hline Water $\mathrm{kg} / \mathrm{m}^{3}$ & 160 & 160 & 160 & 160 \\
\hline Fine aggregate $\mathrm{kg} / \mathrm{m}^{3}$ & 575 & 535 & $59 \mathrm{~F}$ & 535 \\
\hline Coarse aggregate $\mathrm{kg} / \mathrm{m}^{3}$ & 1275 & 1245 & 1270 & 1250 \\
\hline $\mathrm{w} / \mathrm{c}$ ratio & 0.5 & 0.385 & 0.5 & 0.385 \\
\hline MIX & 31 & 32 & 41 & 42 \\
\hline W/C RATIO & 0.5 & 0.385 & 0.5 & 0.385 \\
\hline Density (average) $\mathrm{kg} / \mathrm{m}^{3}$ & 2305 & 2325 & 2315 & 2330 \\
\hline Cement kg/m³ & 320 & 415 & 320 & 415 \\
\hline Water $\mathrm{kg} / \mathrm{m}^{3}$ & 160 & 160 & 160 & 160 \\
\hline Fine aggregate $\mathrm{kg} / \mathrm{m}^{3}$ & 570 & 525 & 585 & 525 \\
\hline Coarse aggregate $\mathrm{kg} / \mathrm{m}^{3}$ & 1255 & 1225 & 1250 & 1230 \\
\hline $\mathrm{w} / \mathrm{c}$ ratio & 0.5 & 0.385 & 0.5 & 0.385 \\
\hline
\end{tabular}

Table 2. Properties of concrete with mixed aggregates.

\begin{tabular}{|c|c|c|c|c|c|c|c|}
\hline TYPE & $\mathrm{W} / \mathrm{C}$ & \multicolumn{2}{|c|}{ COMPRESSIVE } & \multicolumn{2}{|c|}{ CYLINDER } & FLEXURAL & ELASTIC MODULUS \\
\hline OF & RATIO & STRENC & & & ENGTH & STRENGTH & DYN STATIC \\
\hline \multicolumn{2}{|c|}{ MIX } & 7DAY & \multicolumn{3}{|c|}{ 28DAY } & & \\
\hline & & $\mathrm{N} / \mathrm{mm}^{2}$ & $\mathrm{~N} / \mathrm{m}$ & & $\mathrm{N} / \mathrm{mm}^{2}$ & $\mathrm{~N} / \mathrm{mm}^{2}$ & $\mathrm{~N} / \mathrm{mm}^{2} \mathrm{~N} / \mathrm{mm}^{2}$ \\
\hline 11 & 0.5 & 34.00 & 39. & & 29.02 & 6.46 & 37902.114790 .3 \\
\hline 12 & 0.385 & 48.10 & 53. & & 32.65 & 7.50 & 39968.718226 .5 \\
\hline 21 & 0.5 & 33.21 & 37. & & 29.33 & 7.58 & 40508.114660 .4 \\
\hline 22 & 0.385 & 47.33 & 52. & & 31.76 & 8.17 & 39057.215172 .9 \\
\hline 31 & 0.5 & 34.73 & 40. & & 27.84 & 6.13 & 36992.413322 .7 \\
\hline 32 & 0.385 & 47.81 & 52. & & 30.71 & 6.97 & 38163.716269 .6 \\
\hline 41 & 0.5 & 35.66 & 41. & & 27.22 & 7.61 & 38676.914500 .0 \\
\hline 42 & 0.385 & 42.93 & 50. & & 32.69 & 7.73 & 37597.614672 .1 \\
\hline Gravel & 0.385 & 36.83 & 41. & & 29.3 & 4.41 & 46922.823480 .2 \\
\hline 0.5 & & 46.49 & 53. & & 37.98 & 5.33 & 47557.824033 .5 \\
\hline
\end{tabular}


Table 3. Properties of concrete with mixed aggregates.

\begin{tabular}{|c|c|c|c|c|c|c|}
\hline \multirow{2}{*}{$\begin{array}{l}\text { TYPE } \\
\text { OF } \\
\text { MIX }\end{array}$} & \multirow{2}{*}{$\begin{array}{c}\text { W/C } \\
\text { RATIO }\end{array}$} & \multicolumn{2}{|c|}{ DENSITY OF } & \multirow{2}{*}{ ISAT } & \multirow[t]{2}{*}{$\begin{array}{c}\text { SHRINKAGE } \\
\times 10^{-4} \mathrm{~mm}\end{array}$} & \multirow{2}{*}{$\begin{array}{c}\text { PULSE } \\
\text { VELOCITY } \\
\mathrm{km} / \mathrm{s}\end{array}$} \\
\hline & & dry & saturated & & & \\
\hline 11 & 0.5 & 2219 & 2330 & Average & 3.024 & 4.279 \\
\hline 12 & 0.385 & 2276 & 2363 & low & 3.73 & 4.273 \\
\hline 21 & 0.5 & 2271 & 2353 & low & 2.68 & 4.109 \\
\hline 22 & 0.385 & 2289 & 2377 & low & 3.268 & 4.230 \\
\hline 31 & 0.5 & 2184 & 2297 & Average & 3.42 & 4.012 \\
\hline 32 & 0.385 & 2231 & 2312 & low & 3.81 & 4.103 \\
\hline 41 & 0.5 & 2227 & 2314 & low & 3.01 & $3.9 \mathrm{~g} 4$ \\
\hline 42 & 0.385 & 2243 & 2331 & Low & 3.63 & 4.112 \\
\hline \multirow{2}{*}{ Gravel } & 0.5 & 2403 & 2454.80 & Low & 1.17 & 4.76 \\
\hline & 0.385 & 2411 & 2457.70 & Low & 2.97 & 4.79 \\
\hline
\end{tabular}

Note: a) $11 \%$ - 30\% London brick aggregate $+70 \%$ Gravel; b) $12 \%$ - $30 \%$ London brick aggregate $+70 \%$ Gravel; c) $21 \%$ - 30\% Sand-lime brick aggregate $+70 \%$ Gravel; d) $22 \%-30 \%$ Sand-lime brick aggregate $+70 \%$ Gravel; e) $31 \%$ - 40\% London brick aggregate $+60 \%$ Gravel; f) $32 \%-40 \%$ London brick aggregate $+60 \%$ Gravel; g) $41 \%$ - 40\% Sand-lime brick aggregate +60\% Gravel; h) $42 \%$ - 40\% Sand-lime brick aggregate $+60 \%$ Gravel.

Initial surface absorption

Shrinkage

Frost Resistance
$150 \mathrm{~mm}$ cubes.

$150 \mathrm{~mm}$ cubes.

$150 \mathrm{~mm}$ cubes.

All specimen were cured in water at $20^{\circ} \mathrm{C}$ for 42 days before testing.

\section{Experimental Testing Results}

Results obtained from testing of various test samples are summarized below and are also shown in Tables 3-17.

\subsection{Compressive Strength}

Compressive strength tests on cubes at 7 days and 28 days showed that the rate of development of strength of mixed aggregate concrete was similar to normal aggregate concrete.

Specimen with $30 \%$ and $40 \%$ of gravel replaced by coarse crushed waste construction brick and waste sand-lime brick aggregates developed satisfactory compressive strengths at the first attempt.

On testing cylinders for 28 days compressive strength, it was observed that the cylinder strength varied from $58 \%$ to $78 \%$ of cube strength as compared to $60 \%$ to $67 \%$ for gravel. Table 4 gives the 28 day compressive strengths of cubes and cylinders for concrete with different percentages of brick and gravel mixed aggregates concrete.

\subsection{Flexural Strength}

$150 \times 150 \times 750 \mathrm{~mm}$ beams were cast for determining the flexural strength of concrete with brick plus gravel aggregates mixed in the ratio of 30:70 and 40:60 
Table 4. Cube and cylinder strengths of different concretes.

\begin{tabular}{ccccc}
\hline $\begin{array}{c}\text { TYPE } \\
\text { OF }\end{array}$ & W/C & $\begin{array}{c}\text { CUBE } \\
\text { STRENGTH }\end{array}$ & \multicolumn{2}{c}{$\begin{array}{c}\text { CYLINDER } \\
\text { STRENGTH }\end{array}$} \\
\hline MIX & & $\mathrm{N} / \mathrm{mm}^{2}$ & $\mathrm{~N} / \mathrm{mm}^{2}$ & $\%$ \\
\hline & & & & \\
11 & 0.50 & 39.30 & 29.02 & 73.84 \\
12 & 0.385 & 53.24 & 32.65 & 61.33 \\
21 & 0.50 & 37.14 & 29.33 & 78.97 \\
22 & 0.385 & 52.43 & 31.76 & 60.58 \\
31 & 0.50 & 40.31 & 27.84 & 69.06 \\
32 & 0.385 & 52.74 & 30.71 & 58.23 \\
41 & 0.50 & 41.00 & 27.22 & 66.39 \\
42 & 0.385 & 50.87 & 32.69 & 64.26 \\
Gravel & 0.50 & 41.34 & 25.17 & 60.90 \\
& 0.385 & 53.81 & 36.37 & 67.60 \\
\hline
\end{tabular}

Table 5. Flexural strength of concrete with mixed aggregates.

\begin{tabular}{cccc}
\hline $\begin{array}{c}\text { TYPE OF } \\
\text { MIX }\end{array}$ & $\begin{array}{c}\text { W/C } \\
\text { RATIO }\end{array}$ & $\begin{array}{c}\text { COMPRESSIVE } \\
\text { STRENGTH } \\
\text { 28DAY N/mm }\end{array}$ & $\begin{array}{c}\text { FLEXURAL } \\
\text { STRENGTH } \\
\mathrm{N}^{2} \mathrm{~mm}^{2}\end{array}$ \\
\hline 11 & 0.5 & 39.30 & 6.46 \\
12 & 0.385 & 53.24 & 7.50 \\
21 & 0.5 & 37.14 & 7.58 \\
22 & 0.385 & 52.43 & 8.17 \\
31 & 0.5 & 40.31 & 6.13 \\
32 & 0.385 & 52.74 & 6.97 \\
41 & 0.5 & 41.00 & 7.61 \\
42 & 0.385 & 50.87 & 7.73 \\
Gravel & 0.5 & 41.34 & 4.41 \\
& 0.385 & 53.81 & 5.33 \\
\hline
\end{tabular}

Table 6. Static modulus of elasticity of concrete with mixed aggregates.

\begin{tabular}{cccc}
\hline $\begin{array}{c}\text { TYPE } \\
\text { OF }\end{array}$ & $\begin{array}{c}\text { W/C } \\
\text { RATIO }\end{array}$ & $\begin{array}{c}\text { COMPRESSIVE } \\
\text { STRENGTH }\end{array}$ & $\begin{array}{c}\text { STATIC MODULUS } \\
\text { OF ELASTICITY }\end{array}$ \\
\hline MIX & & 28 DAY & N/mm ${ }^{2}$ \\
& & N/mm & 14790.3 \\
11 & 0.5 & 39.30 & 18226.5 \\
12 & 0.385 & 53.24 & 14660.4 \\
21 & 0.5 & 37.14 & 15172.9 \\
22 & 0.385 & 52.43 & 13322.7 \\
31 & 0.5 & 40.31 & 16269.6 \\
32 & 0.385 & 52.74 & 14500.0 \\
41 & 0.5 & 41.00 & 14672.1 \\
42 & 0.385 & 50.87 & 23480.2 \\
Gravel & 0.5 & 41.34 & 24033.5 \\
& 0.385 & 53.81 &
\end{tabular}


Table 7. Dynamic modulus of elasticity of concrete with mixed aggregates.

\begin{tabular}{cccc}
\hline TYPE OF MIX & W/C RATIO & $\begin{array}{c}\text { COMPRESSIVE STRENGTH } \\
\text { N/mm }\end{array}$ & $\begin{array}{c}\text { DYNAMIC MODULUS OF } \\
\text { ELASTICITY N/mm }\end{array}$ \\
\hline 11 & 0.5 & 39.30 & 37902.1 \\
12 & 0.385 & 53.24 & 39968.7 \\
21 & 0.5 & 37.14 & 40508.1 \\
22 & 0.385 & 52.43 & 37597.6 \\
31 & 0.5 & 40.31 & 36992.4 \\
32 & 0.385 & 52.74 & 38163.7 \\
41 & 0.5 & 41.00 & 38676.9 \\
42 & 0.385 & 50.87 & 39057.2 \\
Gravel & 0.5 & 41.34 & 46922.8 \\
& 0.385 & 53.81 & 47557.8 \\
\hline
\end{tabular}

Table 8. Ultrasonic pulse velocities of concrete with mixed aggregates.

\begin{tabular}{cccc}
\hline $\begin{array}{c}\text { TYPE } \\
\text { OF }\end{array}$ & W/C RATIO & $\begin{array}{c}\text { COMPRESSIVE } \\
\text { STRENGTH }\end{array}$ & $\begin{array}{c}\text { PULSE VELOCITY } \\
\text { Km/s }\end{array}$ \\
\hline 11 & 0.5 & 39.30 & 4.279 \\
12 & 0.385 & 53.24 & 4.273 \\
21 & 0.5 & 37.14 & 4.109 \\
22 & 0.385 & 52.43 & 4.230 \\
31 & 0.5 & 40.31 & 4.012 \\
32 & 0.385 & 52.74 & 4.103 \\
41 & 0.5 & 41.00 & 3.984 \\
42 & 0.385 & 50.87 & 4.112 \\
& 0.5 & 41.34 & 4.76 \\
Gravel & 0.385 & 53.81 & 4.79 \\
\hline
\end{tabular}

Table 9. Comparison of empirical and experimental moduli of elasticity by pulse velocity measurements.

\begin{tabular}{|c|c|c|c|c|c|}
\hline \multirow{2}{*}{$\begin{array}{c}\text { Type of Mix } \\
11\end{array}$} & \multirow{2}{*}{$\begin{array}{c}\text { Pulse } \\
\text { Velocity Km/s } \\
4.3\end{array}$} & \multicolumn{2}{|c|}{$\begin{array}{c}\text { Empirical Moduli } \\
\text { Static Dynamic N/mm² }\end{array}$} & \multicolumn{2}{|c|}{$\begin{array}{l}\text { Experimental Moduli } \\
\text { Static Dynamic N/mm }\end{array}$} \\
\hline & & 24,500 & 34,000 & 14,790 & 37,902 \\
\hline 12 & 4.3 & 24,500 & 34,000 & 18,226 & 39,968 \\
\hline 21 & 4.1 & 20,000 & 30,500 & 14,660 & 40,508 \\
\hline 22 & 4.2 & 22,000 & 32,000 & 15,173 & 37,597 \\
\hline 31 & 4.0 & 18,000 & 29,000 & 13,322 & 36,992 \\
\hline 32 & 4.1 & 20,000 & 30,500 & 14,660 & 40,508 \\
\hline 41 & 3.98 & 18,000 & 29,000 & 13,322 & 36,992 \\
\hline 42 & 4.1 & 20,000 & 30,500 & 14,660 & 40,508 \\
\hline Gravel 0.5 & 4.76 & 30,500 & 39,000 & 23,480 & 46,923 \\
\hline 0.385 & 4.79 & 43,000 & 49,000 & 24,033 & 47,558 \\
\hline
\end{tabular}


Table 10. Densities of concrete with mixed aggregates.

\begin{tabular}{cccc}
\hline $\begin{array}{c}\text { TYPE OF } \\
\text { MIX }\end{array}$ & W/C RATIO & DENSITY OF CONCRETE $\left(\mathrm{kg} / \mathrm{m}^{3}\right)$ \\
Dry Saturated
\end{tabular}

Table 11. Shrinkage of concrete with mixed aggregates.

\begin{tabular}{ccc}
\hline TYPE OF MIX & W/C RATIO & SHRINKAGE $\times 10^{-4} \mathrm{~mm}$ \\
\hline 11 & 0.5 & 3.024 \\
12 & 0.385 & 3.73 \\
21 & 0.5 & 2.68 \\
22 & 0.385 & 3.268 \\
31 & 0.5 & 3.42 \\
32 & 0.385 & 3.81 \\
41 & 0.5 & 3.01 \\
42 & 0.385 & 3.69 \\
& 0.5 & 1.176 \\
Gravel & 0.385 & 2.976 \\
\hline
\end{tabular}

Table 12. Summary-Frost resistance test on concrete with mixed aggregates (50 cycles).

\begin{tabular}{cccc}
\hline TYPE OF MIX & W/C RATIO & $\begin{array}{c}\text { EXPANSION } \\
\%\end{array}$ & $\begin{array}{c}\text { REDUCTION IN DYNAMIC } \\
\text { MODULUS \% }\end{array}$ \\
\hline 11 & 0.50 & 0.04 & 23.7 \\
21 & 0.50 & 0.06 & 15.0 \\
31 & 0.50 & 0.076 & 28.4 \\
41 & 0.50 & 0.057 & 14.8 \\
12 & 0.385 & 0.035 & 24.1 \\
22 & 0.385 & 0.036 & 3.0 \\
32 & 0.385 & 0.068 & 28.5 \\
42 & 0.385 & 0.046 & 5.7 \\
Gravel & 0.50 & 0.048 & 7.1 \\
& 0.385 & 0.07 & 14.4 \\
\hline
\end{tabular}


Table 13. Comparison of compressive strengths of concrete specimen before and after Frost Resistance Tests.

\begin{tabular}{ccccc}
\hline TYPE OF & W/C & INITIAL & RESIDUAL & VARIATION \\
\hline MIX & RATIO & $\begin{array}{r}\text { STRENGTH } \\
\text { N/mm }{ }^{2}\end{array}$ & $\begin{array}{c}\text { STRENGTH } \\
\text { N/mm }{ }^{2}\end{array}$ & $\%$ \\
\hline 11 & 0.50 & 45.05 & 43.55 & 3.33 \\
12 & 0.385 & 50.85 & 49.05 & 3.53 \\
21 & 0.50 & 47.25 & 46.05 & 2.54 \\
22 & 0.385 & 52.05 & 51.6 & 0.86 \\
31 & 0.50 & 42.51 & 40.73 & 4.18 \\
32 & 0.385 & 50.76 & 48.53 & 4.39 \\
41 & 0.50 & 46.30 & 45.19 & 2.39 \\
42 & 0.385 & 51.64 & 50.9 & 1.43 \\
Gravel & 0.50 & 41.34 & 40.32 & 1.02 \\
Gravel & 0.385 & 53.81 & 53.11 & 1.3 \\
\hline
\end{tabular}

Table 14. Performance of concrete with normal construction brick waste aggregate and gravel in the ratio of 30:70, respectively, in frost resistance.

\begin{tabular}{lcccccc}
\hline \multicolumn{5}{c}{ Sample No.31. $40 \%$ London brick $+60 \%$ Gravel W/C Ratio 0.50 Observations } \\
\hline Cycles & Start & 10 & 20 & 30 & 40 & 50 \\
Length $\left({ }^{*} 0.01 \mathrm{~mm}\right)$ & 248.25 & 258.5 & 271 & 285 & 266 & 268.5 \\
Weight $(\mathrm{g}):$ & 11870.5 & 11,878 & 11,877 & 11,875 & 11877.5 & 1877.5 \\
R frequency (Hz): & 4131.5 & 3725.5 & 3721 & 3693 & 3641.5 & 3607.5 \\
Dyn. Mod. (N/mm’): & 40522.5 & 32,963 & 32,900 & 32,425 & 31502.8 & 30920.4
\end{tabular}

Reduction in Dyn. Modulus-23.7\%, Increase in length-0.04\%

Sample No.12. 30\% London brick + 70\% Gravel W/C Ratio 0.385 Observations

$\begin{array}{lcccccc}\text { Cycles } & \text { Start } & 10 & 20 & 30 & 40 & 50 \\ \text { Length }\left({ }^{*} 0.01 \mathrm{~mm}\right): & 255.2 & 261.7 & 273.5 & 286.5 & 271 & 273 \\ \text { Weight }(\mathrm{g}): & 11919.3 & 11,926 & 11,926 & 11,904 & 11,874 & 11925.5 \\ \text { R frequency }(\mathrm{Hz}): & 4104 & 3594.5 & 3627 & 3595 & 3585 & 3573.5 \\ \text { Dyn. Mod. (N/mm’) } & 40149.5 & 30807.7 & 31,382 & 30,847 & 30,656 & 30462.5\end{array}$

Reduction in Dyn. mod. $=24.13 \%$ Increase in length $=0.035 \%$

respectively, vide BS 1881: Part 109: 1983. Test beams were cured for 28 days before testing. The tests for flexural strength was carried out vide BS 1881: Part 118: 1983 with third point loading. Table 5 gives the values of flexural strength against average compressive strength of concrete with mixed aggregates.

It was observed that the flexural strength of concrete with mixed aggregates varied from 6.1 to $7.7 \mathrm{~N} / \mathrm{mm}^{2}$ i.e. $15 \%$ to $20 \%$ of the 28 day compressive strength as compared to flexural strengths varying from 4.4 to $5.3 \mathrm{~N} / \mathrm{mm}^{2}$ i.e. $9.9 \%$ to $10.7 \%$ of the 28 day compressive strengths for gravel concrete. Hence flexural 
Table 15. Performance of concrete with normal construction brick aggregate and gravel in the ratio of 40:60, respectively, in frost resistance test.

\begin{tabular}{|c|c|c|c|c|c|c|}
\hline \multicolumn{7}{|c|}{ Sample No.31. 40\% London brick $+60 \%$ Gravel W/C Ratio 0.50 Observations } \\
\hline Cycles & Start & 10 & 20 & 30 & 40 & 50 \\
\hline Length $\left({ }^{\star} 0.01 \mathrm{~mm}\right)$ & 239 & 249 & 264 & 277 & 256 & 261 \\
\hline Weight (g): & 11,769 & 11,774 & 11,777 & 11,778 & 11,777 & 11,778 \\
\hline $\mathrm{R}$ frequency $(\mathrm{Hz})$ : & 4011 & 3523 & 3501 & 3483 & 3421.2 & 3391 \\
\hline Dyn. Mod. (N/mm'): & 37,868 & 29,226 & 28,879 & 28,598 & 27,569 & 27,089 \\
\hline \multicolumn{7}{|c|}{ Reduction in dynamic modulus $-28.46 \%$ Increase in length $=0.044 \%(\max 0.076 \%)$} \\
\hline \multicolumn{7}{|c|}{ Sample No.32. 40\% London brick + 60\% Gravel W/C Ratio 0.385 Observations } \\
\hline Cycles & Start & 10 & 20 & 30 & 40 & 50 \\
\hline Length $\left({ }^{*} 0.01 \mathrm{~mm}\right)$ : & 265 & 274 & 287 & 299 & 287 & 293 \\
\hline Weight $(\mathrm{g})$ : & 11,817 & 11,821 & 11,824 & 11828 & 11,794 & 11,801 \\
\hline $\mathrm{R}$ frequency $(\mathrm{Hz})$ : & 4003 & 3491 & 3427 & 3415 & 3402 & 3382 \\
\hline Dyn. Mod.(N/mm' ) & 37,871 & 28,813 & 27,781 & 27,600 & 27,377 & 27,062 \\
\hline
\end{tabular}

Table 16. Performance of concrete with sand-lime brick aggregate and gravel in the ratio of 30:70, respectively, in frost resistance test.

\begin{tabular}{|c|c|c|c|c|c|c|}
\hline \multicolumn{7}{|c|}{ Sample No.21. $70 \%$ Gravel + 30\% Sand-lime brick U/C Ratio 0.50 Observations } \\
\hline Cycles & Start & 10 & 20 & 30 & 40 & 50 \\
\hline Length $\left({ }^{\star} 0.01 \mathrm{~mm}\right)$ : & 214.7 & 212.7 & 220 & 245 & 216 & 217.5 \\
\hline Weight (g): & 11,962 & 11,966 & 11967.5 & 11,968 & 11967 & 11968.5 \\
\hline $\mathrm{R}$ frequency $(\mathrm{Hz})$ & 4186 & 4012 & 3971.5 & 3926 & 3860.5 & 3859 \\
\hline Dyn. Mod. N/mm²): & 4193 & 38514.8 & 37742.8 & 36920 & 35656.8 & 35631.3 \\
\hline \multicolumn{7}{|c|}{ Reduction in dyn. mod. $=15 \%$ Increase in length $=0.005 \%(\max 0.06 \%)$} \\
\hline \multicolumn{7}{|c|}{ Sample No.22. 70\% Gravel $+30 \%$ Sand-lime brick W/C Ratio 0.385 Observations } \\
\hline Cycles & Start & 10 & 20 & 30 & 40 & 50 \\
\hline Length $\left({ }^{*} 0.01 \mathrm{~mm}\right)$ & 235.5 & 233.25 & 242 & 253.5 & 234.5 & 238 \\
\hline Weight $(\mathrm{g})$ : & 11947.5 & 11949.5 & 11,949 & 11949.5 & 1949 & 11,947 \\
\hline $\mathrm{R}$ frequency $(\mathrm{Hz})$ : & 4112 & 4064 & 4064.5 & 4063 & 4057.5 & 4051 \\
\hline Dyn.Mod. (N/mm'): & 40402.9 & 39461.6 & 39,485 & 39474.2 & 39,337 & 39,217 \\
\hline
\end{tabular}

strength values for concrete with mixed aggregates are $7 \%$ higher on average than concrete with Thames Valley gravel.

Table 5 shows the variation in flexural strength of mixed aggregates concrete as compared to brick aggregate concrete and gravel concrete. It can be observed from Table 5 that flexural strength of concrete with brick aggregates is slightly lower than gravel concrete. The flexural strength of concrete with mixed aggregates is higher than both brick aggregate concrete as well as gravel concrete. 
Table 17. Performance of concrete with sand-lime brick aggregate and gravel in the ratio of 40:60, respectively, in frost resistance test.

\begin{tabular}{|c|c|c|c|c|c|c|}
\hline \multicolumn{7}{|c|}{ Sample No.41. 60\% Gravel + 40\% Sand-lime brick W/C Ratio 0.50 Observations } \\
\hline Cycles & Start & 10 & 20 & 30 & 40 & 50 \\
\hline Length $\left({ }^{\star} 0.01 \mathrm{~mm}\right)$ & 203.4 & 201.6 & 208 & 232 & 203 & 206 \\
\hline Weight $(\mathrm{g})$ : & 11,859 & 11,864 & 11,867 & 11,869 & 11,867 & 11,869 \\
\hline $\mathrm{R}$ frequency $(\mathrm{Hz})$ : & 4166 & 4001 & 3970 & 3916 & 3873 & 3844 \\
\hline Dyn. Mod. (N/mm') & 41,164 & 37,965 & 37,388 & 36,413 & 35,577 & 35,050 \\
\hline \multicolumn{7}{|c|}{ Reduction in dynamic modulus $=14.8 \%$ Increase in length $=0.005 \%(\max 0.057 \%)$} \\
\hline \multicolumn{7}{|c|}{ Sample No.42. $60 \%$ Gravel $+40 \%$ Sand-lime brick W/C Ratio 0.385 Observations } \\
\hline Cycles & Start & 10 & 20 & $3 \mathrm{O}$ & 40 & 50 \\
\hline Length $\left({ }^{\star} 0.01 \mathrm{~mm}\right)$ & 231 & 229 & 240 & 254 & 243 & 244 \\
\hline Weight $(\mathrm{g})$ : & 11,938 & 11,939 & 11,942 & 11,943 & 11,942 & 11,943 \\
\hline $\mathrm{R}$ frequency $(\mathrm{Hz})$ : & 4104 & 4041 & 4027 & 4008 & 3997 & 3984 \\
\hline Dyn. Mod. (N/mm') & 40,214 & 38,985 & 38,733 & 38,390 & 38,162 & 37,916 \\
\hline
\end{tabular}

It was observed that failure in flexure across the section of test beams occurred by a crack through the mortar, through the brick aggregate particles and around the gravel particles in case of concrete with brick aggregates plus gravel whereas the failure crack propagated through the mortar and around the gravel particles in the case of the control mix with Thames valley gravel as coarse aggregate. No gravel particles were observed to fail but failure occurred along the bond surface between the mortar and rounded gravel particles.

\subsection{Stress/Strain Behavior}

\subsubsection{Static Modulus of Elasticity}

$150 \mathrm{~mm}$ diameter, $300 \mathrm{~mm}$ long cylinders were prepared for determining the static modulus of elasticity in compression. Strains were recorded for every incremental load increase. Table 6 gives the values of static modulus of elasticity for concrete with mixed aggregates.

The average static modulus of elasticity was observed to vary between $60 \%$ and $75 \%$ for concrete with crushed brick and gravel aggregates mixed in the ratio of 30:70 respectively and between $54 \%$ and $66 \%$ for concrete with crushed brick and gravel mixed in the ratio of 40:60 respectively, as compared to concrete with gravel aggregates only.

The values of static modulus of elasticity were observed to increase with increase in the compressive strength of concrete. The average static modulus of elasticity for concrete with brick aggregate plus gravel in the ratio 30:70 respectively is $37 \%$ lower as compared to concrete with Thames Valley gravel whereas concrete with brick aggregates plus gravel in the ratio of 40:60 respectively is $41 \%$ lower. The reduction in static modulus of elasticity of concrete with mixed 
aggregates is due to lower modulus of elasticity of normal construction brick and sand-lime brick aggregate.

\subsubsection{Dynamic Modulus of Elasticity}

Test beams $150 \times 150 \times 750 \mathrm{~mm}$ were cast for carrying out the dynamic modulus of elasticity tests. The specimens were cured for 28 days before testing for dynamic modulus of elasticity. Table 7 gives the values of dynamic modulus of elasticity for concrete with mixed aggregates.

The average resonant frequencies observed for concrete with normal construction brick aggregate plus gravel and sand-lime brick aggregate plus gravel were observed to be about $9 \%$ to $10 \%$ and $8 \%$ to $9 \%$ lower than for concrete with Thames Valley gravel aggregate only with an average value of $2981 \mathrm{~Hz}$.

The dynamic modulus of elasticity for concrete with normal construction brick aggregate plus gravel varied from 36,992 to $38,163 \mathrm{~N} / \mathrm{mm}^{2}$ whereas that for concrete with sand-lime brick aggregate plus gravel varied from 37,597 to 40,508 $\mathrm{N} / \mathrm{mm}^{2}$. Values of dynamic modulus for concrete with Thames Valley gravel aggregate varied from 46,922 to $47,557 \mathrm{~N} / \mathrm{mm}^{2}$. Hence the average dynamic modulus for concrete with normal construction brick aggregate plus gravel and sand-lime brick aggregate plus gravel is $77 \%$ and $80 \%$ respectively of the value for concrete with Thames Valley gravel aggregate. The reduction in dynamic modulus of elasticity of concrete with mixed aggregates is due to lower resonant frequencies and lower densities of crushed brick aggregates.

\subsection{Ultrasonic Pulse Velocity}

Ultrasonic pulse velocity tests for observing the velocity of pulses across the mixed aggregate concrete specimen were carried out as per BS 1881: Part 203: 1986. $150 \mathrm{~mm}$ cubes were cured for 28 days as per BS 1881: Part 111: 1983 before testing for the pulse velocity. Pulse velocities observed for different concretes are given in Table 8.

Average pulse velocity across concrete with normal construction brick aggregate plus gravel was observed to be $4.27 \mathrm{~km} / \mathrm{s}$ for aggregate ratio of $30: 70 \mathrm{respec}-$ tively and $4.05 \mathrm{~km} / \mathrm{s}$ for the aggregate ratio of 40:60 respectively for average values of static moduli of elasticity of $16,508 \mathrm{~N} / \mathrm{mm}^{2}$ and $14,796 \mathrm{~N} / \mathrm{mm}^{2}$ dynamic moduli of elasticity of 38,935 and $37,577 \mathrm{~N} / \mathrm{mm}^{2}$ respectively. similarly, the average pulse velocity with sand-lime brick aggregate plus gravel was observed to be $4.15 \mathrm{~km} / \mathrm{s}$ for aggregate ratio of $30: 70$ respectively and $4.0 \mathrm{~km} / \mathrm{s}$ for the aggregate ratio of 40:60 respectively for average values of static moduli of elasticity of 14916 and 14,585 N/mm ${ }^{2}$ and dynamic moduli of elasticity of 39,052 and 38,866 $\mathrm{N} / \mathrm{mm}^{2}$ respectively. For concrete with Thames Valley gravel as coarse aggregate, average pulse velocity was observed to be $4.8 \mathrm{~km} / \mathrm{s}$ for average values of static modulus of elasticity of $23,757 \mathrm{~N} / \mathrm{mm}^{2}$ and dynamic modulus of elasticity of $47,240 \mathrm{~N} / \mathrm{mm}^{2}$. Hence the variation of pulse velocity in the case of concrete with normal construction brick aggregate plus gravel in the ratios 30:70 and 40:60 is $11 \%$ and $15.5 \%$ lower, respectively, as compared to concrete with gravel. Concrete with sand-lime brick waste aggregate plus gravel in the ratios 30:70 and 
40:60 have been observed to have pulse velocities $13.5 \%$ and $16.5 \%$ lower, respectively, as compared to pulse velocity in concrete with Thames Valley gravel aggregate. It was observed that pulse velocities, static moduli and dynamic moduli of elasticity obtained from experimental investigations did not correlate with the values given in BS 1881: Part 203: 1986 for concrete with different types of brick aggregates mixed with gravel aggregates in different percentages.

\subsection{Initial Surface Absorption (ISAT)}

ISAT tests were carried out on cubes as per BS 1881: Part 5: 1970. The results were compared with the typical results of ISAT tests given by Concrete Society Technical Report No.31.

ISAT results obtained from tests on concrete with normal construction brick aggregates plus gravel mixed in the ratios 30:70 and 40:60 respectively, revealed that surface absorption was average and almost 50\% higher amounts of water were absorbed in both cases as compared to concrete with gravel and w/c ratio of 0.50 . The absorption was, however, similar to concrete with gravel, for w/c ratio of 0.385 . Low surface absorption was observed for concrete with sand-lime brick aggregates plus gravel in the ratios of $30: 70$ and 40:60 for w/c ratios of $0.385 \&$ 0.5 similar to concrete with gravel only.

\subsection{Shrinkage}

Shrinkage tests were carried out in accordance with RILEM Recommendation CPC 9-Measurement of shrinkage and swelling. $100 \times 100 \times 500 \mathrm{~mm}$ prismatic specimen were cast and cured in water at $20^{\circ} \mathrm{C}$ for 28 days. The prisms were then accurately measured and stored at $20^{\circ} \mathrm{C}$ and $65 \%$ relative humidity for ninety days after which they were measured accurately to observe the shrinkage values. Table 11 gives the shrinkage of concrete with mixed aggregates.

Shrinkage of concrete with normal construction brick waste aggregates plus gravel in the ratio of 30:70 was almost one and a half times higher than concrete with gravel only for w/c ratio of 0.50 , whereas for w/c ratio of 0.385 , shrinkage was $25 \%$ higher. For the ratio of $40: 60$ of normal construction brick aggregate and gravel respectively, shrinkage was observed to be twice the value of concrete with gravel only for w/c ratio of 0.50 , whereas for w/c ratio of 0.385 , shrinkage was observed to be about $30 \%$ higher than concrete with gravel only.

Shrinkage of concrete with Sand-lime brick waste aggregates plus gravel in the ratio of 30:70 was almost one and a quarter times higher than concrete with gravel only for w/c ratio of 0.50 , whereas for w/c ratio of 0.385 , shrinkage was about $10 \%$ higher. For the ratio of 40:60 of sand-lime brick waste aggregate and gravel respectively, shrinkage was observed to be twice the value of concrete with gravel only, for w/c ratio of 0.50 whereas for w/c ratio of 0.385 , shrinkage was observed to be about $22 \%$ higher than concrete with gravel only.

\subsection{Frost Resistance}

The RILEM recommendation on methods of carrying out and reporting freeze 
thaw tests on concrete without deicing chemicals were followed to carry out an investigation on the comparative performance of concrete with different types of coarse brick waste aggregates and Thames Valley gravel. $100 \times 100 \times 500 \mathrm{~mm}$ prisms were cast and cured for 28 days in water at $20^{\circ} \mathrm{C}$ before subjecting them to freezing and thawing cycles. One specimen of each strength was cast with two thermistors at the centre so as to monitor the temperature of specimen during the test. Length change and variation in dynamic modulus were monitored during the test and the residual compressive strength of each specimen recorded at the end of the test. Table 12 gives a summary of the performance of mixed aggregates concrete in frost resistance test. Table 13 gives the comparison of compressive strengths of dummy specimens and specimens of frost resistance test after completion of 50 cycles of freezing and thawing. Concrete with normal construction brick waste aggregate plus gravel mixed in the ratios of 30:70 and 40:60 respectively, both started expanding continuously on cyclic freezing and thawing and the large expansions were accompanied by a rapid decrease in dynamic modulus, as shown in Table 14 and Table 15 . The dynamic modulus decreased by almost $20 \%$ in the first twenty cycles after which the decrease was observed to be gradual for w/c ratios of both 0.50 and 0.385 . Net reduction in dynamic modulus after fifty cycles was observed to be $23.7 \%$ and $28.46 \%$ for w/c ratio of 0.50 against $7.33 \%$ for concrete with Thames Valley gravel. The associated maximum increase in length was $0.073 \%$ and $0.076 \%$ as compared to a decrease in length of $0.048 \%$ for concrete with Thames Valley gravel.

For w/c ratio of 0.385 , the reduction in dynamic modulus was observed to be $24.13 \%$ and $28.53 \%$ respectively for ratios of $30: 70$ and $40: 60$ of normal construction brick aggregate and gravel in concrete. The reduction in dynamic modulus of concrete with Thames Valley gravel with similar compressive strength was observed to be $14.39 \%$. The corresponding increase in length was observed to be $0.035 \%$ and $0.068 \%$ compared to $0.071 \%$ for concrete with Thames Valley gravel. Concrete with normal construction brick waste aggregate plus gravel showed continuously increasing expansions for the first thirty cycles of freezing and thawing. Concrete with normal construction brick waste aggregate and gravel in the ratio of 40:60 respectively (by weight) showed larger expansions as compared to concrete with normal construction brick waste aggregate and gravel in the ratio of 30:70 respectively. The large increase in length and accompanying rapid reduction in dynamic modulus is due to the continuous expansion of normal construction brick aggregates which have high absorption of about $20 \%$ and comprise of large sized pores with higher quantity of freezable water. Since the specimens were fully saturated on start of testing, expansion of water in the aggregates on freezing pressurizes excess water out of the aggregate into the surrounding mortar. On further cooling, this water expands and exerts dilative pressures on the mortar resulting in microcracking within the mortar, along the bond surface between mortar and aggregate particles and also within the aggregate particles. The situation is worsened by the differential expansion/ contraction between the brick aggregates, mortar and gravel particles hence cyc- 
lic freezing and thawing increases microcracking thereby resulting in loss of strength along with length increases.

The length of specimen increased continuously over the first thirty cycles after which there was slight decrease in length in the next ten cycles after which again the length started increasing. This behavior is possibly due to the presence of a few closed pores in brick aggregate which were not open initially. The expansion over the first thirty cycles of freezing and thawing exerted sufficient pressure on these pores to open up and provide some relief for the excess water to be accommodated. After some excess water was accommodated in these pores, the specimen showed slight contractions for the next ten cycles after which the specimen again started increasing in length. The behavior of concrete with normal construction brick waste aggregates plus gravel is entirely different from concrete with Thames Valley gravel only. Concrete with Thames Valley gravel shows slight contraction in the first twenty cycles after which there is a slight increase in length. The corresponding reduction in dynamic modulus is gradual. Concrete with normal construction brick waste aggregate plus gravel shows large expansions in first thirty cycles with a large reduction in dynamic modulus. Thereafter the expansions are small and continuous along with a gradual decrease in dynamic modulus. Table 13 shows the variation in compressive strength of the dummy specimen and of the specimen after fifty cycles of freezing and thawing. Concrete with normal construction brick waste aggregates plus gravel in the ratio of $30: 70$ by weight respectively shows a variation of $3.33 \%$ to $3.53 \%$ for w/c ratios of 0.50 and 0.385 , respectively. For concrete with ratio of normal construction brick aggregate and gravel of 40:60 respectively, the variation in compressive strength is $4.18 \%$ to $4.39 \%$ for w/c ratios of 0.50 and 0.385 , respectively. Concrete with Thames valley gravel shows a variation of $1.02 \%$ to $1.3 \%$ for w/c ratios of 0.50 and 0.385 respectively. Hence the reduction of compressive strength for concrete with normal construction brick waste aggregate plus gravel in the ratio of 30:70 by weight respectively is three times and for the ratio of 40:60 by weight respectively is four to four and a half times as compared to concrete with Thames Valley gravel only.

Table 16 and Table 17 gives the performance of sand-lime brick waste plus gravel aggregate concrete in frost resistance test. For concrete with sand-lime brick waste aggregate plus gravel mixed in the ratios of 30:70 and 40:60 respectively, the reduction in dynamic modulus after fifty cycles was observed to be 15 and $14.8 \%$ for w/c ratio of 0.50 against $7.33 \%$ for concrete with Thames Valley gravel. The associated maximum increase in length was $0.06 \%$ and $0.057 \%$ as compared to a decrease in length of $0.048 \%$ for concrete with Thames Valley gravel. For w/c ratio of 0.385 , the reduction in dynamic modulus was observed to be $3 \%$ and $5.7 \%$ respectively for ratios of 30:70 and 40:60 of normal construction brick aggregate and gravel in concrete. The reduction in dynamic modulus of concrete with Thames Valley gravel with similar w/c ratio was observed to be $14.39 \%$. The corresponding increases in length were observed to be $0.036 \%$ and $0.046 \%$ compared to $0.071 \%$ for concrete with Thames Valley gravel. 
Concrete with sand-lime brick aggregate plus gravel behaved somewhat similarly to concrete with Thames Valley gravel. There was a slight contraction in the first ten cycles after which the specimen started expanding gradually until thirty cycles of cyclic freezing after which there was again a slight decrease in length over the next ten cycles followed by gradual expansion. This behavior is possibly due to the presence of a few closed pores inside the brick aggregates which open up on exertion of dilative pressures of cyclic cooling. The slight contraction later on is due to accommodation of some excess expanding water in these pores which open up after about thirty cycles. Later on, the specimen again starts expanding due to dilative pressures on cooling.

The reduction in dynamic modulus in concrete with sand-lime brick waste aggregate plus gravel is gradual and is one-third to half the value for concrete with Thames Valley gravel. The lower loss of strength is due to the fine pores present in sand-lime brick aggregate which, although having an absorption of $10 \%$, has little of freezable water. The expansion of brick aggregates could be similar to the expansion of mortar thereby reducing the micro cracking inside the concrete as compared to concrete with Thames Valley gravel only, thereby reducing the loss of strength. Concrete with sand-lime brick waste aggregates plus gravel in the ratio of 30:70 by weight respectively shows a variation in compressive strength of $2.54 \%$ to $0.86 \%$ for w/c ratios of 0.50 and 0.385 , respectively. For concrete with ratio of sand-lime brick waste aggregate and gravel of 40:60 respectively, the variation in compressive strength is $2.39 \%$ to $1.43 \%$ for $\mathrm{w} / \mathrm{c} \mathrm{ra}$ tios of 0.50 and 0.385 , respectively. Concrete with Thames Valley gravel shows a variation of 1.02 to $1.3 \%$ for $\mathrm{w} / \mathrm{c}$ ratios of 0.50 and 0.385 , respectively

\section{Conclusions}

The rate of development of strength of mixed aggregate concrete was observed to be similar to that of normal aggregate concrete. Mixed aggregates concrete developed satisfactory compressive strengths as compared to concrete with gravel aggregate. Flexural strengths were higher by about $5 \%$, the average static modulus of elasticity was observed to decrease by $35 \%$ to $40 \%$, and average dynamic modulus for concrete with brick aggregate plus gravel was $20 \%$ to $23 \%$ lower than the value for concrete with Thames Valley gravel aggregate. The variation of pulse velocity in the case of concrete with brick aggregate plus gravel is $7 \%$ to $13 \%$ lower as compared to concrete with gravel. Average densities for concrete with brick aggregates plus gravel were $4 \%$ to $6 \%$ lower than concrete with gravel. ISAT results obtained from tests on concrete with brick aggregates plus gravel showed that surface absorption was almost 50\% higher for higher w/c ratio but was however similar to concrete with Thames Valley gravel, for lower $\mathrm{w} / \mathrm{c}$ ratio. Shrinkage of concrete with brick aggregates plus gravel was almost one and a half times higher than concrete with gravel for higher w/c ratio whereas for lower w/c ratio shrinkage was $25 \%$ higher.

Frost resistance of mixed aggregate concrete depends on the absorption and pore size of brick aggregate. Mixed aggregate concrete with normal construction 
brick aggregate mixed with gravel started expanding continuously on cyclic freezing and thawing and large expansions resulted in rapid decrease in dynamic modulus whereas concrete with sand-lime brick aggregate mixed with gravel showed better frost resistance than gravel concrete for w/c ratio of 0.385 .

Keeping in view the characteristics of concrete with waste brick aggregates mixed with normal aggregates, in the ratios of 30:70 respectively, there are no appreciable differences while in the ratios of 40:60 respectively, shrinkage is larger along with lower moduli of elasticity and loss of strength on cyclic freezing and thawing. Such concrete is well suited for low rise construction, pavements and other structures not lying in the areas subjected to freeze thaw in cold regions.

\section{References}

[1] Kibriya, T. (2002) Durability of Concrete with Crushed Brick Coarse Aggregates. 8th Islamic Countries Conference on Statistical Sciences, 21-24 December 2002, University of Bahrain, Bahrain, 311-317.

[2] Kibriya. T. (2003) Investigations on High Strength Concrete with Crushed Brick Coarse Aggregates. Science Technology and Development, 22, 1-4.

[3] Kibriya. T. (2005) Crushed Burnt Clay Bricks as Aggregates for High Strength Concrete. Proceedings of McMat 2005, Joint ASCE/ASME/SES Conference on Mechanics and Materials, 1-3 June 2005, Baton Rouge, Louisiana, 1-6.

[4] Kibriya, T. and Speare, P.R.S. (1996) The Use of Crushed Brick Coarse Aggregates in Concrete. International Congress on "Concrete in the Service of Mankind", 24-28 June 1996, Dundee, 204-213.

[5] Kibriya, T. (1991) Properties of Concrete with Crushed Brick Aggregates. Ph.D. Thesis, City University, London.

[6] Kibriya, T. and Speare, P.R.S. (1996) The Use of Crushed Brick Coarse Aggregates in Concrete. In: Dhir, Ravindra K. \& Dyer Thomas D., Eds., Concrete in the Service of Mankind-Concrete for Environment Enhancement and Protection, E \& FN SPON, London, 495-503.

[7] Kibriya, T. (2001) Investigations on Frost Resistance of Concrete with Crushed Brick Coarse Aggregates. 41st Annual Convention, IEP, 26-28 May 2001, Karachi, $1-8$.

[8] Kibriya, T. (2002) Investigations on Sulphate Resistance of Concrete with Crushed Brick Coarse Aggregates. The Pakistan Engineer, Institution of Engineers, Pakistan, 28-30. 
Submit or recommend next manuscript to SCIRP and we will provide best service for you:

Accepting pre-submission inquiries through Email, Facebook, LinkedIn, Twitter, etc. A wide selection of journals (inclusive of 9 subjects, more than 200 journals)

Providing 24-hour high-quality service

User-friendly online submission system

Fair and swift peer-review system

Efficient typesetting and proofreading procedure

Display of the result of downloads and visits, as well as the number of cited articles Maximum dissemination of your research work

Submit your manuscript at: http://papersubmission.scirp.org/

Or contact wjet@scirp.org 